\title{
Effect of organic waste and NPK fertilizer on potato yield and soil fertility
}

\author{
Muhammad Zahoor ${ }^{1}$, Muhammad Afzal ${ }^{1}$, Murad Ali ${ }^{*}$, Wisal \\ Mohammad $^{2}$, NaseemKhan ${ }^{1}$, Muhammad Adnan ${ }^{3}$, Azaz Ali $^{1}$ and \\ Muhammad Saeed ${ }^{4}$ \\ 1. Department of Soil and Environmental Sciences, University of Agriculture, Peshawar, Pakistan \\ 2. Soil Science division, Nuclear Institute of food and Agriculture, Peshawar, Pakistan \\ 3. Department of Agriculture, the University of Swabi, Pakistan \\ 4. Cereal Crops Research Institute Pirsabak, Nowshera, Pakistan \\ *Corresponding author's email: muradses@gmail.com
}

Citation

Muhammad Zahoor, Muhammad Afzal, Murad Ali, Wisal Mohammad, Naseem Khan, Muhammad Adnan, Azaz $\mathrm{Ali}^{1}$ and Muhammad Saeed. Effect of organic waste and NPK fertilizer on potato yield and soil fertility. Pure and Applied Biology. Vol. 5, Issue 3, pp439-445. http://dx.doi.org/10.19045/bspab.2016.50056

\begin{tabular}{llll}
\hline \hline Received: 02/02/2016 & Revised: 05/05/2016 & Accepted: 22/05/2016 First: 28/05/2016
\end{tabular}

\section{Abstract}

A field experiment was conducted to examine the effect of organic waste and NPK fertilizers on macro and micronutrients concentration in potato straw and on yield at Nuclear Institute of food and Agriculture Peshawar, Pakistan during 2012. Fifteen treatments of various organic and inorganic fertilizers were applied to potato crop each replicated three times. After harvesting of the crop, potato yield was recorded. For soil fertility analysis 90 soil samples from two depths (015 and $15-30 \mathrm{~cm}$ ) and 45 straw samples were also collected and analyzed. Fertilizer doses showed significant effect on potato yield and soil fertility parameter. The treatments (Filter cake + full NPK) and (Municipal solid waste + full NPK) showed high yield and significant effect on NPK and micronutrients concentrations in potato straw. The lowest concentrations of micronutrients in soil and potato straw were observed mainly in treatment (PK recommended dose) and control. It can be concluded from this experiment that the conjunctive use of inorganic fertilizers with organic waste further accelerated the beneficial effect of inorganic fertilizers on soil and plants. The treatments (Filter cake + full NPK) and (MSW + full NPK) seemed to be the appropriate dose for sustainable production of potato.

Key words: Potato; Fertilizer; Manure; Municipal solid waste; F cake; Yield

\section{Introduction}

Pakistan is basically an agricultural country. The soils are $100 \%$ deficient in organic matter (O.M less than 1\%) and in major plant nutrients including nitrogen and phosphours. Soil organic matter plays a major role in maintaining soil quality and also effect the production of the crop [1]. The beneficial effects of organic manures are manifested through increase in soil organic matter and humus over the period. Soil organic matter and humus acts in several ways; it serves as slow release source of plant nutrients to the crops and increases water holding capacity to maintain the water regime of the soil and acts as a buffer against change in soil $\mathrm{pH}$ [2]. Using the residues of agricultural activities, municipal waste, improve soil physical and chemical properties and also the fertility and 
production capacity [3]. Composts are important source to maintain and restore soil fertility particularly in those countries where the organic matter content of the soil is low. Nutritional stress including widespread nutrient deficiencies, low organic matter content, unbalanced use of fertilizers, poor physical condition and soil fertility are the major limiting factors causing low crop production in Pakistan [4]. The balance application of chemial fertilizer is very nessery for valuable producation. However, their imbalance use, high rates,availability time is not properly manage and some nutrient has loses from the soil is the serious porblum for the farmers [5].

Potato (Solanum tuberosum L.) belong to family solanaceae is the fourth most important food crop in the world on the basis of production, Its cultivation is quite intensive in northern west Punjab and north west Khyber Pakhtunkhwa. Three crops of potato can be grown in a year, a spring and an autumn crop in the plains and a summer crop in the hilly area at higher altitudes. The area under potato is 137.7 thousand hectares with production of 2554.2 thousand tonnes with average yield is $22.7 \mathrm{t} \mathrm{ha}^{-1}$, In Khyber Pakhtunkhwa it is grown on the area of 9.2 thousand hectares and yield is 123.1 thousand tonnes with average yield of $13.1 \mathrm{t} \mathrm{ha}^{-1}$ ) [6]. The potato crop is high nitrogen $(\mathrm{N})$ feeder. Organic matter slowly releases plant nutrients and thus contributing to efficient crop production and sustainable soil fertility. Fertilizer application is the best way of increasing yield per unit area. It is believed that NPK fertilizers improve both yield and quality of potato tubers. The quality of potato tuber optimum growth and production require high amount of potassium fertilizer [7], but its recovery of $\mathrm{K}$ is often quite low. The efficiency of NPK fertilizers can be further increased by the use of micronutrients [8]. The aim of present study was to determine the effect of different doses of fertilizers on nutritional composition of prominent local variety of potato i.e. Core. Results of this study would be to improve the nutritional quality of potato by the use of suitable combination of NPK fertilizers and organic waste.

\section{Materials and methods}

Location: A field experiment was conducted during autumn season 2012. The experiment was conducted at the Research Farm of Nuclear Institute for Food and Agriculture (NIFA), Tarnab (longitude $71^{0} 50$, latitude $34^{0} 01$ ), Peshawar, Pakistan. The site is located at the altitude of $400 \mathrm{~m}$ above sea level in the Peshawar valley of Khyber Pakhtunkhwa and has cool climate in winter and warm to hot in the summer. Soil of the experimental site was clay loam [Order: Inceptisols, Sub order: Ustepts, Soil great group: Haplustepts, Soil Sub group: Udic Haplustepts,

\section{Experimental design}

The experiment was conducted to according randomize complete block (RCBD) with fifteen treatments and each treatment was replicated three times. Potato was sown on ridges made $30 \mathrm{~cm}$ high and $80 \mathrm{~cm}$ apart. Different treatments i.e. $\mathrm{N}, \mathrm{P}_{2} \mathrm{O}_{5}, \mathrm{~K}_{2} \mathrm{O}$, FYM, MSW and filter cake were applied alone or in various combinations including control, farm yard manure, municipal solid waste, NPK full (250- 120-120 $\mathrm{kg} \mathrm{ha}^{-1}$ ), tomato residue + half NPK, filter cake + half NPK, tomato residue + full NPK, filter cake + full NPK, recommended $\mathrm{PK}$, tomato residue alone, filter cake alone, FYM + half NPK, MSW + half NPK, FYM + full NPK and MSW + full NPK. The fertilizers were applied at the time of sowing; half of the nitrogen was applied at time of sowing and half at the time of earthing off.

\section{Laboratory procedure}

Total nitrogen in Potato straw samples was determined by kjeldhal method suggested by Bremner [9] while total Phosphorous, Potassium and micronutrients was 
determined by the standard procedure described by [10].

Statistical Analysis

The data were recorded and statistically analyzed by using analysis of variance

\begin{tabular}{llcc} 
Table 1. Physico-chemical properties of experimental site & & \\
\cline { 1 - 3 } Properties & Units & Experimental Sites & \\
\cline { 2 - 3 } & & $0-15 \mathrm{~cm}$ & $15-30 \mathrm{~cm}$ \\
\hline Sand & $\%$ & 46 & 20 \\
Silt & $\%$ & 34 & 40 \\
Clay & $\%$ & Clay loam & 40 \\
Texture Class & $\ldots \ldots$ & 8.2 & Clay loam \\
pH & $\ldots \ldots$ & 2.73 & 8.2 \\
Electrical Conductivity & $\mathrm{dS} \mathrm{m}^{-1}$ & 0.94 & 2.4 \\
organic matter & $\mathrm{mg} \mathrm{kg}^{-1}$ & 0.84 & 0.9 \\
Total N & $\mathrm{mg} \mathrm{kg}^{-1}$ & 8.75 & 0.74 \\
Phosphorous & $\mathrm{mg} \mathrm{kg}^{-1}$ & 80 & 6.9 \\
Potassium & $\mathrm{mg} \mathrm{kg}^{-1}$ & 1.71 & 60 \\
Zinc & $\mathrm{mg} \mathrm{kg}^{-1}$ & 8.52 & 1.45 \\
Copper & $\mathrm{mg} \mathrm{kg}^{-1}$ & 5.45 & 7.3 \\
Iron & $\mathrm{mg} \mathrm{kg}^{-1}$ & 14.37 & 5.01 \\
Manganese & $\mathrm{mg} \mathrm{kg}^{-1}$ & & 10.5 \\
\hline
\end{tabular}

\section{Results and discussions}

Effect of organic waste and NPK fertilizer on micronutrients concentration in soil

Organic waste and NPK fertilizer significantly $(\mathrm{P} \leq 0.05)$ affected the micronutrient concentration in soil. The result showed that maximum $\mathrm{Zn}$ concentration were found (176.8 and 113.3 $\left.\mathrm{mg} \mathrm{Kg}{ }^{-1}\right)$ in the treatment where MSW+ half NPK, Filter cake + full NPK were applied at two soil depth $0-15 \mathrm{~cm}$ and $15-30 \mathrm{~cm}$ respectively. The maximum $\mathrm{Cu}$ concentration was observed $\left(5.4 \mathrm{mg} \mathrm{Kg}^{-1}\right)$ in the treatments (Filter cake + half NPK and F.Y.M + half NPK) at soil depths of (0-15 $\mathrm{cm})$ and $(15-30 \mathrm{~cm})$ respectively. The highest concentration of $\mathrm{Fe}$ (448.6 and $402.6 \mathrm{mg} \mathrm{Kg}^{-}$ ${ }^{1}$ ) was observed in the treatment (FYM + half NPK) at soil depths of $(0-15 \mathrm{~cm})$ and $(15-30$ techniques. Treatment means were tested by using least significant differences (LSD) at 5\% level of probability [11]. $\mathrm{cm})$ respectively. High $\mathrm{Mn}$ concentrations (14.1 and $12.4 \mathrm{mg} \mathrm{Kg}^{-1}$ ) were observed in the treatment (Filter cake+ full NPK and FYM + half NPK) at soil depth $(0-15 \mathrm{~cm})$ and $(15-30$ $\mathrm{cm})$ respectively. The lowest concentrations of $\mathrm{Zn}, \mathrm{Cu}, \mathrm{Fe}$ and $\mathrm{Mn}$ were observed in control presented in table. 2 at 0-15 and 15-30 $\mathrm{cm}$ soil depth. The results was in line with those of Diacono et al., [12] who also reported that $\mathrm{Zn}, \mathrm{Cu}, \mathrm{Fe}$ and $\mathrm{Mn}$ concentration increase with applications of organic manure. Asiegbu et al. [13] Found that $\mathrm{N}, \mathrm{P}$ and $\mathrm{K}$ fertilizers were more efficient than the organic manures in supplying $\mathrm{N}, \mathrm{P}$ and $\mathrm{K}$ to the growing plant at least in the short run, further supported by Banin et al. [14] that FYM increase the uptake of $\mathrm{N}, \mathrm{Fe}$ and $\mathrm{Zn}$ and also enhanced $\mathrm{P}$ uptake. 
Table2. Effect of organic waste and NPK fertilizer on micro nutrients concentration in soil

\begin{tabular}{|c|c|c|c|c|c|c|c|c|}
\hline \multirow[t]{2}{*}{ Treatments } & \multicolumn{2}{|c|}{$\mathrm{Zn}\left(\mathrm{mg} \mathrm{Kg}^{-1}\right)$} & \multicolumn{2}{|c|}{$\mathrm{Cu}\left(\mathrm{mg} \mathrm{Kg}^{-1}\right)$} & \multicolumn{2}{|c|}{$\mathrm{Fe}\left(\mathrm{mg} \mathrm{Kg}^{-1}\right)$} & \multicolumn{2}{|c|}{$\operatorname{Mn}\left(\mathrm{mg} \mathrm{kg}^{-1}\right)$} \\
\hline & $0-15 \mathrm{~cm}$ & $15-30 \mathrm{~cm}$ & $0-15$ & $15-30$ & $0-15$ & $15-30$ & $0-15$ & $15-30$ \\
\hline Control & $0.6 f$ & $0.3 \mathrm{j}$ & $2.8 \mathrm{e}$ & $2.5 \mathrm{~h}$ & $41.0 \mathrm{~h}$ & $23.0 \mathrm{j}$ & $4.1 \mathrm{~h}$ & $2.6 \mathrm{~g}$ \\
\hline PK only Recommended & $1.8 \mathrm{e}$ & 2.0ef & $5.1 \mathrm{ab}$ & $4.2 \mathrm{de}$ & $47.6 \mathrm{~h}$ & $31.0 \mathrm{ij}$ & $7.5 f$ & $7.3 \mathrm{e}$ \\
\hline FYM alone & $3.3 \mathrm{ab}$ & $2.2 \mathrm{ef}$ & $4.9 \mathrm{ab}$ & 4.1ef & $120.0 f$ & $87.3 \mathrm{~g}$ & $8.1 \mathrm{e}$ & $10.6 b$ \\
\hline Tomato residue & $2.7 \mathrm{~d}$ & $1.9 \mathrm{fg}$ & $4.6 \mathrm{bcd}$ & $4.9 \mathrm{bc}$ & $56.2 \mathrm{gh}$ & 38.6hi & $6.1 \mathrm{~g}$ & $8.4 \mathrm{~d}$ \\
\hline Munciple solid waste & $3.5 \mathrm{ab}$ & $2.8 \mathrm{bc}$ & $4.0 \mathrm{~d}$ & $5.4 \mathrm{ab}$ & $162.6 \mathrm{de}$ & $115.3 \mathrm{f}$ & $7.6 \mathrm{f}$ & $7.6 \mathrm{e}$ \\
\hline Filter Cake & $2.6 \mathrm{~d}$ & $2.3 \mathrm{de}$ & $3.9 \mathrm{~d}$ & $5.4 \mathrm{ab}$ & $70.0 \mathrm{~g}$ & $43.0 \mathrm{~h}$ & $10.2 \mathrm{c}$ & $9.5 \mathrm{c}$ \\
\hline NPK recommended & $3.4 \mathrm{ab}$ & $2.2 \mathrm{ef}$ & $4.7 \mathrm{abc}$ & $5.4 \mathrm{ab}$ & $215.3 \mathrm{c}$ & $196.0 \mathrm{c}$ & $12.0 \mathrm{~b}$ & $10.1 b$ \\
\hline FYM+ half NPK & $2.9 \mathrm{~cd}$ & $2.2 \mathrm{ef}$ & $4.2 \mathrm{~cd}$ & $5.5 \mathrm{a}$ & $448.6 \mathrm{a}$ & $402.6 \mathrm{a}$ & $14.5 \mathrm{a}$ & $12.4 \mathrm{a}$ \\
\hline Tomato residue + half NPK & $3.6 \mathrm{a}$ & $1.2 \mathrm{i}$ & $5.1 \mathrm{ab}$ & $5.2 \mathrm{ab}$ & $445.3 \mathrm{a}$ & $394.3 \mathrm{a}$ & $7.3 \mathrm{f}$ & $6.4 f$ \\
\hline MSW +half NPK & $3.6 \mathrm{a}$ & $3.1 b$ & 4.9abc & $4.6 \mathrm{~cd}$ & $170.7 \mathrm{~d}$ & $156.6 \mathrm{~d}$ & $10.2 \mathrm{c}$ & $8.6 \mathrm{~d}$ \\
\hline filter Cake + half NPK & $3.3 \mathrm{ab}$ & $2.6 \mathrm{~cd}$ & $5.4 \mathrm{a}$ & $4.5 \mathrm{cde}$ & $54.7 \mathrm{gh}$ & $42.6 \mathrm{~h}$ & $8.1 \mathrm{e}$ & $7.3 \mathrm{e}$ \\
\hline FYM + full NPK & $3.5 \mathrm{ab}$ & $1.3 \mathrm{hi}$ & $5.2 \mathrm{ab}$ & $4.4 \mathrm{de}$ & $151.0 \mathrm{e}$ & $139.3 \mathrm{e}$ & $12.3 b$ & $10.7 b$ \\
\hline Tomato residue + full NPK & $3.6 \mathrm{a}$ & $2.9 \mathrm{bc}$ & $4.7 \mathrm{abc}$ & $3.3 \mathrm{~g}$ & $311.3 b$ & $283.6 b$ & $10.2 \mathrm{c}$ & $8.5 \mathrm{~d}$ \\
\hline MSW + full NPK & $3.2 \mathrm{bc}$ & $1.6 \mathrm{gh}$ & $4.9 \mathrm{ab}$ & $3.6 \mathrm{fg}$ & $223.3 \mathrm{c}$ & $202.3 \mathrm{c}$ & $9.5 \mathrm{~d}$ & $8.2 \mathrm{~d}$ \\
\hline Filter cake +full NPK & $3.4 \mathrm{ab}$ & $3.7 \mathrm{a}$ & $5.1 \mathrm{ab}$ & $3.5 \mathrm{~g}$ & $223.0 \mathrm{c}$ & $201.3 \mathrm{c}$ & $14.1 \mathrm{a}$ & $10.4 \mathrm{~b}$ \\
\hline $\mathrm{LSD}_{0.05}$ & 0.36 & 0.34 & 0.68 & 0.51 & 16.5 & 9.95 & 0.38 & 0.54 \\
\hline
\end{tabular}

Effect of organic waste and NPK fertilizer on micro nutrients concentration in potato straw

The micronutrient concentration $(\mathrm{Zn}, \mathrm{Cu}, \mathrm{Fe}$ and $\mathrm{Mn}$ ) in potato straw were significantly $(\mathrm{P}$ $\leq 0.05$ ) increased with the organic waste and NPK fertilizers as compared to control and presented in Table.3. Highest zinc concentration $\left(27.00 \mathrm{mg} \mathrm{Kg}^{-1}\right)$ was observed in the treatment where only Tomato residue was treated which was significantly higher from rest of treatment and lowest zinc concentration was recorded $\left(5.53 \mathrm{mg} \mathrm{Kg}^{-1}\right)$ in control. Similarly maximum $\mathrm{Cu}$ concentration was noted $\left(29.26 \mathrm{mg} \mathrm{Kg}^{-1}\right)$ in the treatment where only Tomato residue was applied and the minimum concentration (11.46 $\mathrm{mg} \mathrm{Kg}^{-1}$ ) was in control. The $\mathrm{Fe}$ concentration was in range (1314.0-1376.4 $\mathrm{mg} \mathrm{Kg}^{-1}$ ) and highest in treatment (Filter cake + full NPK) and lowest in control. The significant $(\mathrm{P} \leq 0.05)$ highest concentration of $\mathrm{Mn}$ (3.16 mg $\mathrm{Kg}^{-1}$ ) was recorded on municipal solid waste treatment and lowest concentration was observed in control. Micronutrients concentrations of plants is directly associated with their concentrations in soils, their levels significantly differ with plant species, and even can also affected by genotypes within the same species [15].

Table 3. Effect of organic waste and NPK fertilizer on micro nutrients concentration in potato straw

\begin{tabular}{lllll}
\hline \multicolumn{1}{c}{ Treatments } & $\mathbf{Z n}\left(\mathbf{m g ~ K g} \mathbf{~ g}^{-1}\right)$ & $\mathbf{C u}\left(\mathbf{m g ~ K g}^{-1}\right)$ & $\mathbf{F e}\left(\mathbf{m g ~ K g}^{-1}\right)$ & $\mathbf{M n}\left(\mathbf{m g ~ K g}^{-1}\right)$ \\
\hline Control & $5.53 \mathrm{f}$ & $11.46 \mathrm{~g}$ & $1314 \mathrm{bcd}$ & $1.36 \mathrm{e}$ \\
P-K recommended & $13.66 \mathrm{~d}$ & $16.13 \mathrm{~cd}$ & $1343.7 \mathrm{abcd}$ & $2.18 \mathrm{bc}$ \\
FYM & $20.66 \mathrm{bc}$ & $17.50 \mathrm{c}$ & $1290.3 \mathrm{~d}$ & $1.63 \mathrm{de}$ \\
Tomato residue & $27.00 \mathrm{a}$ & $29.26 \mathrm{a}$ & $1367.3 \mathrm{ab}$ & $2.26 \mathrm{bc}$ \\
Muncipal solid waste & $14.66 \mathrm{~d}$ & $27.63 \mathrm{a}$ & $1329.7 \mathrm{abcd}$ & $3.16 \mathrm{a}$ \\
Filter Cake NPK & $21.00 \mathrm{bc}$ & $13.83 \mathrm{ef}$ & $1304 \mathrm{~cd}$ & $1.29 \mathrm{e}$
\end{tabular}




\begin{tabular}{lllll} 
recommended & $23.00 \mathrm{~b}$ & $17.56 \mathrm{c}$ & $1302.7 \mathrm{~cd}$ & $1.90 \mathrm{~cd}$ \\
FYM + half NPK & $10.00 \mathrm{e}$ & $16.10 \mathrm{~cd}$ & $1365.3 \mathrm{ab}$ & $2.18 \mathrm{bc}$ \\
Tomato residue + half NPK & $21.33 \mathrm{bc}$ & $20.03 \mathrm{~b}$ & $1339 \mathrm{abcd}$ & $2.19 \mathrm{bc}$ \\
MSW + half NPK & $21.33 \mathrm{bc}$ & $20.10 \mathrm{~b}$ & $1346 \mathrm{abcd}$ & $2.11 \mathrm{bc}$ \\
Filter Cake + half NPK & $19.66 \mathrm{c}$ & $15.13 \mathrm{de}$ & $1315.3 \mathrm{bcd}$ & $1.44 \mathrm{e}$ \\
FYM + full NPK & $11.66 \mathrm{de}$ & $12.20 \mathrm{fg}$ & $1322.7 \mathrm{abcd}$ & $2.13 \mathrm{bc}$ \\
Tomato residue + full NPK & $18.66 \mathrm{c}$ & $14.10 \mathrm{def}$ & $1357.3 \mathrm{abc}$ & $2.08 \mathrm{bc}$ \\
MSW + full NPK & $21.00 \mathrm{c}$ & $12.26 \mathrm{fg}$ & $1355.7 \mathrm{abc}$ & $2.35 \mathrm{~b}$ \\
Filter cake + full NF & $23.00 \mathrm{~b}$ & $18.30 \mathrm{bc}$ & $1376.7 \mathrm{a}$ & $2.10 \mathrm{bc}$ \\
\hline LSD & 3.23 & 2.26 & 60.84 & 0.39 \\
\hline
\end{tabular}

Effect of organic waste and NPK fertilizer on NPK concentration in potato straw.

Combine application of organic waste and NPK fertilizers significantly $(\mathrm{P} \leq 0.05)$ increased NPK concentrations in potato straw over control. The significantly $(\mathrm{P} \leq 0.05)$ higher $\mathrm{N}$ concentration was observed $(2.25 \mathrm{~g}$ $100 \mathrm{~g}^{-1}$ ) in treatment where MSW + full NPK was applied and statistically different from rest of the treatments. Lowest $\mathrm{N}$ concentration was recorded in control (Table 4). The highest $P$ concentration was observed

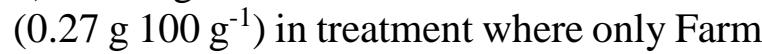
yard manure was applied and statistically similar to treatment where MSW + full NPK was treated and lowest Phosphorous concentration was noted in control $(0.27 \mathrm{~g}$ $\left.100 \mathrm{~g}^{-1}\right)$. The $\mathrm{K}$ concentration was maximum (3.66 g $\left.100 \mathrm{~g} \mathrm{~g}^{-1}\right)$ in treatment where FYM was applied and lowest in control $\left(2.66 \mathrm{~g} 100 \mathrm{~g}^{-}\right.$ $\left.{ }^{1}\right)$. Nitrogen, Phosphorus and Potassium uptake by plants increase with increase in FYM application [16]. Phosphorus and FYM application had significant $(\mathrm{P} \leq 0.05)$ effect on both tuber and shoot weight showing that there was positive interaction between
Phosphorous and FYM on tuber and shoot weight.

Effect of organic waste and NPK fertilizer on Yield and plant height of potato.

The data regarding potato tuber yield is presented in table.5, the results indicated that the combined used of organic and inorganic fertilizer increased potato yield significantly $(\mathrm{P} \leq 0.05)$ over control. Treatment where MSW + half NPK showed maximum yield (20.66 kg plot $^{-1}$ ) and yield was decreased up to $\left(10.16 \mathrm{~kg} \mathrm{plot}^{-1}\right)$ in control. Potato plant height was in range $33.80-54.46 \mathrm{~cm}$. The result was agreed with findings of Baishya [17] who observed that the highest tuber yield was obtained with the application of 50 $\% \mathrm{NPK}$ of the recommended dose through inorganic fertilizers and remaining 50\% from PM. Similar result were founded by Moshileh et al. [7] who revealed that the significant increased were noted in plant height and chlorophyll concentration with the increase of potash levels. Tikhonov et al. [18] found that NPK application increased yield and enhanced starch content when compared with NP and NK.

Table 4. Effect of organic waste and NPK fertilizer on NPK concentration in potato straw

\begin{tabular}{llll}
\hline Treatments & $\mathrm{N}\left(\mathrm{g} 100 \mathrm{~g}^{-1}\right)$ & $\mathrm{P}\left(\mathrm{g} 100 \mathrm{~g}^{-1}\right)$ & $\mathrm{K}\left(\mathrm{g} 100 \mathrm{~g}^{-1}\right)$ \\
\hline Control & $1.616 \mathrm{e}$ & $0.17 \mathrm{~d}$ & $2.66 \mathrm{c}$ \\
$\mathrm{P}-\mathrm{K}$ recommended & $1.676 \mathrm{de}$ & $0.21 \mathrm{c}$ & $2.83 \mathrm{bc}$ \\
FYM & $1.79 \mathrm{bcde}$ & $0.27 \mathrm{a}$ & $3.66 \mathrm{a}$ \\
Tomato residue & $1.58 \mathrm{e}$ & $0.24 \mathrm{abc}$ & $3.50 \mathrm{ab}$ \\
Munciple solid waste & $1.76 \mathrm{cde}$ & $0.21 \mathrm{c}$ & $3.50 \mathrm{ab}$
\end{tabular}




\begin{tabular}{llll} 
Filter Cake & $1.85 \mathrm{bcde}$ & $0.25 \mathrm{ab}$ & $3.16 \mathrm{abc}$ \\
NPK recommended & $2.02 \mathrm{abc}$ & $0.24 \mathrm{abc}$ & $3.66 \mathrm{a}$ \\
FYM + half NPK & $2.05 \mathrm{abc}$ & $0.25 \mathrm{ab}$ & $3.33 \mathrm{abc}$ \\
Tomato residue + half NPK & $2.06 \mathrm{abc}$ & $0.22 \mathrm{bc}$ & $3.50 \mathrm{ab}$ \\
MSW + half NPK & $2.08 \mathrm{ab}$ & $0.24 \mathrm{abc}$ & $3.50 \mathrm{ab}$ \\
Filter Cake + half NPK & $1.96 \mathrm{abcd}$ & $0.22 \mathrm{bc}$ & $3.50 \mathrm{ab}$ \\
FYM +full NPK & $2.05 \mathrm{abc}$ & $0.27 \mathrm{a}$ & $2.8 \mathrm{bc}$ \\
Tomato residue + full NPK & $2.04 \mathrm{abc}$ & $0.23 \mathrm{bc}$ & $3.50 \mathrm{ab}$ \\
MSW+ full NPK & $2.25 \mathrm{a}$ & $0.26 \mathrm{a}$ & $3.50 \mathrm{ab}$ \\
Filter Cake + full NPK & $2.19 \mathrm{a}$ & $0.25 \mathrm{ab}$ & $3.50 \mathrm{ab}$ \\
\hline LSD 0.05 & 0.3 & 0.33 & 0.81 \\
\hline
\end{tabular}

Table 5. Effect of organic waste and NPK fertilizer on yield and plant height of potato

\begin{tabular}{lll}
\hline Treatments & Yield $\left(\mathrm{kg} \mathrm{plot}^{-1}\right)$ & Plant Height $(\mathrm{cm})$ \\
\hline Control & $10.16 \mathrm{ef}$ & $33.80 \mathrm{~h}$ \\
P-K recommended & $12.83 \mathrm{de}$ & $44.26 \mathrm{de}$ \\
FYM & $17.66 \mathrm{abc}$ & $46.33 \mathrm{~cd}$ \\
Tomato residue & $8.167 \mathrm{f}$ & $33.80 \mathrm{~h}$ \\
Munciple solid waste & $14.00 \mathrm{cde}$ & $41.26 \mathrm{fg}$ \\
Filter Cake & $19.16 \mathrm{ab}$ & $50.26 \mathrm{~b}$ \\
NPK recommended & $15.66 \mathrm{bcd}$ & $44.40 \mathrm{de}$ \\
FYM + half NPK & $14.83 \mathrm{bcd}$ & $47.46 \mathrm{c}$ \\
Tomato residue + half NPK & $17.83 \mathrm{abc}$ & $50.13 \mathrm{~b}$ \\
MSW + half NPK & $20.66 \mathrm{a}$ & $51.13 \mathrm{~b}$ \\
Filter Cake + half NPK & $18.83 \mathrm{ab}$ & $45.66 \mathrm{~cd}$ \\
FYM +full NPK & $17.83 \mathrm{abc}$ & $54.46 \mathrm{a}$ \\
Tomato residue + full NPK & $12.66 \mathrm{de}$ & $33.60 \mathrm{~h}$ \\
MSW+ full NPK & $15.00 \mathrm{bcd}$ & $39.60 \mathrm{~g}$ \\
Filter Cake + full NPK & $18.16 \mathrm{abc}$ & $43.13 \mathrm{ef}$ \\
\hline LSD 0.05 & 4.47 & 2.29 \\
\hline
\end{tabular}

\section{Conclusions}

From the present research work it is concluded that combine application of organic waste and inorganic fertilizers could significantly improve soil fertility and nutrients concentration in potato straw. Application of Filter cake + Full NPK and Municipal solid waste + Full NPK could be recommended. The long term use of organic and inorganic fertilizers will be beneficial in achieving sustainable yields.

\section{Authors' contributions}

Conceived and designed the experiments: $\mathrm{M}$ Afzal, Performed the experiments: M Zahoor, M Ali \& W Mohammad, Analyzed the data: N Khan \& M Adnan, Contributed reagents /materials/ analysis tools: W Mohammad \& A Ali, Wrote the paper: M Ali $\&$ M Saeed.

\section{References}

1. Pedra F, Polo A, Ribeiro A, Domingues H (2007). Effects of municipal solid waste compost and sewage sludge on 
mineralization of soil organic matter. Soil BiolBiochem. 39: 1375-1382

2. Upadhayay NC \& Singh JP (2003). The Potato (Production and utilization in SubTropics) Edited by S M Paul Khurana, JS. Minhas and SK Pandey. Published by Mehta Publishers, A 16(East), Naraina II, New Delhi-110028, India.

3. Sposito G L, Lund J \& Chang A C (1982). Trace metal chemistry in arid-zone field soils amended with sewage sludge: fractionation of $\mathrm{Ni}, \mathrm{Cu}, \mathrm{Zn}, \mathrm{Cd}$. and $\mathrm{Pb}$ in solid phases. Soil Sci Soc Am J 46: 260264

4. Rashid A (1994). Annual report of micronutrient project, Land resources Research Institute, NARC, Islamabad

5. Kabir A (1999). Fertilizing with organic wastes to improve physical characteristics of soils. The Daily News International 26th April, 1999

6. Anonymous (2011-2012). Agriculture statistic of Pakistan

7. Moshileh AMA, Errebhi MA \& Motawei MI (2005). Effect of various potassium and nitrogen rates and splitting methods on potato under sandy soil and arid environmental conditions. Amir. J Agric Sci 17(1):01-09

8. Khalil, IA, Habib N \& Ghafoor A (1980). Yield and quality of potato as influenced by nitrogen and potash fertilizer.

9. Bremner JM (1996). Nitrogen-total. In Methods of Soil Analysis Part-3. Chemical methods (D.L. Spark, ed), SSSA, Inc., ASA, Inc., Madison, Wisconsin, USA P: 1085-1122

10. Kue S (1996). Phosphorus. In Methods of Soil Analysis Part-3. Chemical methods
(D.L. Spark, ed), SSSA, Inc., ASA, Inc., Madison, Wisconsin, USA P: 869-919

11. Steel RGD, Torrie J H \& Dickey D A (1997). Principles and Procedures of Statistics. A Biometrical Approach, 3rd Ed. McGraw Hill Book Company, New York, 172-177

12. Diacono M \& Montemurro F (2010). Long-term effects of organic amendments on soil fertility, A review. Agron Sustain Dev 30 (2): 401 - 422

13. Asiegbu JE \& Oikeh S (1995). Evaluation of chemical composition of manures from different organic wastes and their potential for supply of nutrients to tomato in tropical ultisols. Biological Agric Horti 12: 47-60

14. Banin A \& Narorot J (1982). Trunk implanted zinc-bentonite as a source of zinc for apple trees. Plant and Soil 69(1) 85-95.

15. Kabata-Pendias A\& PendiasH (2001). Trace Elements in Soils and Plants. CRC Press Boca Raton FL 3:114

16. Minhas RS \& Sood A (1994) Effect of Inorganics and Organics on the Yield and Nutrient Uptake by Three Crop Rotations on an Acid Alfisol. Journal of Indian Society of Soil Science 42: 257-260

17. Baishya LK (2009). Response of potato varieties to organic and inorganic sources of nutrients. Ph. D. Thesis submitted to Visva-Bharati, West Bengal, India pp 99102

18 Tikhonov NI \& Avdeev YS (1970). Effect of mineral nutrition on the level of traction of phosphorous compound in tuber and on the yield of potatoes. Agrokhimiya 3: 3842. 